\title{
A Decision Support Tool for Building Leasing Strategies to Achieve the Executive Order Mandate for Federal Government Green Buildings
}

\author{
Alexandre E. Cheytanov, Nathan R. Bales, Paramjeet C. Khanna, and Chris Swift, GMU, IEEE
}

\begin{abstract}
U.S. energy prices have risen by $51 \%$ over the last two decades. Buildings account for $39 \%$ of the total energy consumption in the United States. The Federal Government is a significant user of commercial buildings and can save money, improve the environment, and stimulate the green technology sector by migrating to sustainable facilities. The 2009 Executive Order 13514, Federal Leadership in Environmental, Energy, and Economic Performance, set a goal for all federal agencies to make $15 \%$ of their buildings High Performance Sustainable Buildings (HPSB) by 2015.

The Federal Aviation Administration (FAA), which operates over 700 buildings, must convert 15 of its 126 directly leased buildings into HPSB within its existing budget resources. The FAA is currently leasing its building on rent cost per square foot and not Life Cycle Costs (LCCs). This is comparable to buying a car solely based on the sticker price to cargo capacity ratio. There are many more costs to consider over the length of ownership of a car, such as fuel economy, passenger capacity,
\end{abstract} and maintenance costs.

One way for the FAA to meet the target in the existing budget is to incorporate LCC practices in the lease acquisition process. This way buildings are evaluated based on operational costs incurred over the entire lease term to yield net savings.

To evaluate potential savings, an LCC Lease Analysis (LCCLA) decision support tool has been developed to assess leasing options factoring energy and water cost fluctuations for specific buildings in the FAA database. The tool includes three leasing strategies: (1) renewing the existing lease-this option will not help the FAA achieve the E.0.13514; (2) renovating the buildings to meet HPSB standards-the FAA may incur a higher rent, but will be able to satisfy E.0.13514; and (3) relocating the employees to a building that already satisfies E.0.13514. To generate accurate LCCLA results, surrogate data was used to analyze relationships between number of employees per building, cost per square foot, climate zones, and energy costs with respect to lease term, inflation, and energy costs projections.

The analysis has identified fifteen buildings showing either a positive savings, net zero financial impact, or lowest costs. All but one of these buildings is less than 25000 square feet. This is a result of the lower cost of renovating smaller buildings.

The analysis also reveals that full service leases do not allow the FAA to reap the benefits of the green technology. Since the responsibility of paying utilities falls to the lessor, the lessor is in a position to charge a premium rent to cover the stochastic energy costs. If those costs are actually less than what was negotiated, the lessor can pocket the difference. Partial service leases give finer control over money for utility bills. This method of leasing also has the capability of giving immediate feedback as to the performance of the efficiency of the building.

\section{INTRODUCTION}

$T$ HE Federal Aviation Administration (FAA) is a part of the U.S Department of Transportation (DOT). Its main mission is "to provide the safest, most efficient Aerospace System in the world" [1].

In Fiscal Year 2011 (FY2011), the FAA had a budget of 16 billion dollars and employed over 48,000 employees [2]. These employees and their responsibilities can be grouped into three different categories: Air Traffic Organization, Aviation Safety, and Administration Operations. Employees responsible for Air Traffic Organization operate in buildings such as air traffic control towers and radar stations. Employees responsible for Aviation Safety and Administration Operations operate out of over 10,000 FAA owned or leased office buildings. Of these 10,000 buildings 737 fall within E.O.13514 and need to be considered to achieve the $15 \%$ HPSB inventory.

The FAA building inventory is spread throughout the entire United States. All buildings in the FAA are organized into three main service areas (Western, Central, and Eastern). With the exception of Headquarters and Technical Centers, these are considered to be independent service areas regardless of geographical location. Each service area is further broken down into three regions as shown in Fig. 1. [14]

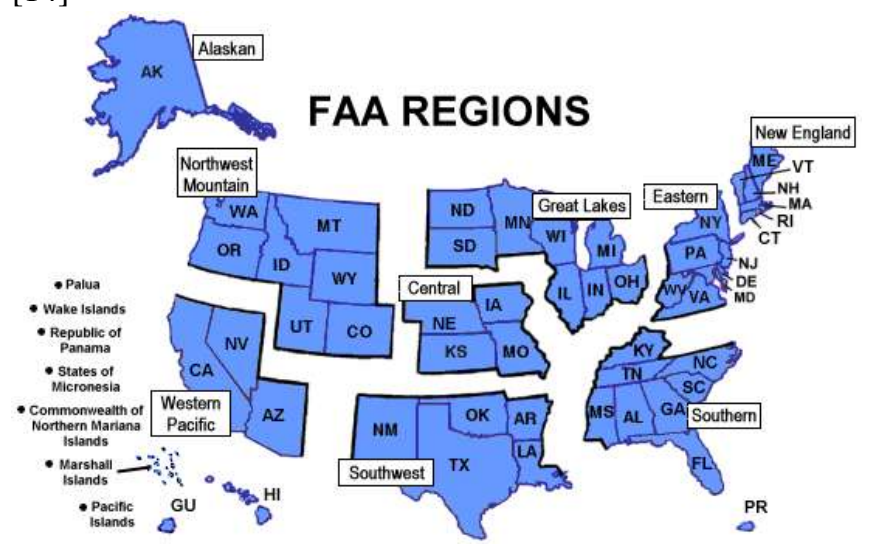

Fig. 1. Map of FAA Regions.

In 2009 President Barack Obama signed Executive Order 13514 (E.O.13514). Titled "Federal Leadership In Environmental, Energy, and Economic Performance," the main goal is for all federal agencies to convert $15 \%$ of their building inventory that are occupied, and are 5000 square 
feet or greater, to High Performance Sustainable Buildings (HPSB) by Fiscal Year 2015. [4]

To meet the E.O.13514, this project is focused on buildings that are directly leased from a private lessor. There are 125 direct leases that the FAA currently holds that fall under the E.O.13514.

The U.S. Department of Energy has predicted that over the next 20 years the price of electricity and natural gas will continue to increase. With the current building inventory of the FAA, the costs to keep these buildings in operation will only increase. Not only will the costs increase, but with such a large inventory of buildings, there is an environmental concern because commercial buildings in the US account for $39.4 \%$ of the US energy consumption, and $38.1 \%$ of the total $\mathrm{CO} 2$ emissions [7]. One solution to both problems is converting office buildings into green/sustainable buildings. Research shows that green buildings can lower operating costs up to $30 \%$ [7]. They can also lower energy use by a $25 \%$ decrease in electricity consumption and an $11 \%$ decrease in water consumption [7]. An added bonus is that job satisfaction of employees housed in green buildings and can be improved by $27 \%$ [7].

\section{CONTEXT}

\section{A. Gap}

Figure 2 shows the gap between the goals set by the Executive Order and how close the FAA is to achieving them. The blue line represents the goals set by the Executive Order 13514 by year. Green line represents where the FAA currently stands with their green buildings. Currently the FAA has successfully converted 3 building out of 737 are HPSB. These buildings consists of owned properties, direct leased, GSA leased, federally owned and FAA controlled buildings.

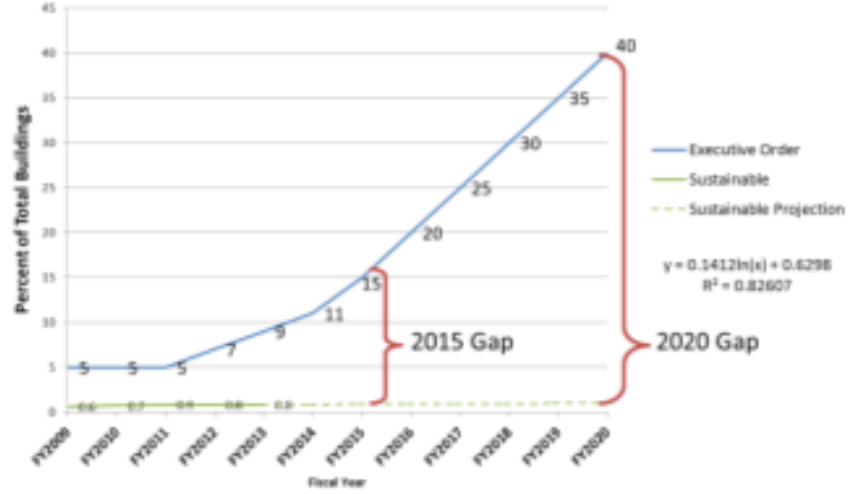

Fig. 2. FAA Building Inventory Gap.

Source: REMS Excel File OCT 12012 from FAA Aviation Logistic Division

The graph shows that $15 \%$ need to be converted into HPSB by 2015. After 2015, the goal is to convert into HPSB by $5 \%$ each year.

\section{DECISION MAKING FACTORS AND INTERACTIONS IN THE BUILDING LEASING PROCESS}

Fig. 3 shows that E.O.13514 is the driving force behind creating demand and reducing cost though economies of scale making green buildings affordable. On the left, the current FAA building are aging and continue to cause and increase in energy consumption, this along with higher energy prices add to the cost to keep these buildings in operation. So far, nothing is happening to increase the number of green buildings or renovate old buildings because green buildings are more expensive. The introduction of E.O.13514 incentivizes the production of green buildings by creating a demand for innovation. There are two alternatives, first is relocation to a green building, the second is to renovate the current buildings to a Leadership in Energy and Environmental Design (LEED) certified building. For direct leases the FAA has adopted a LEED Silver Certification to meet HPSB part of E.O.135134.

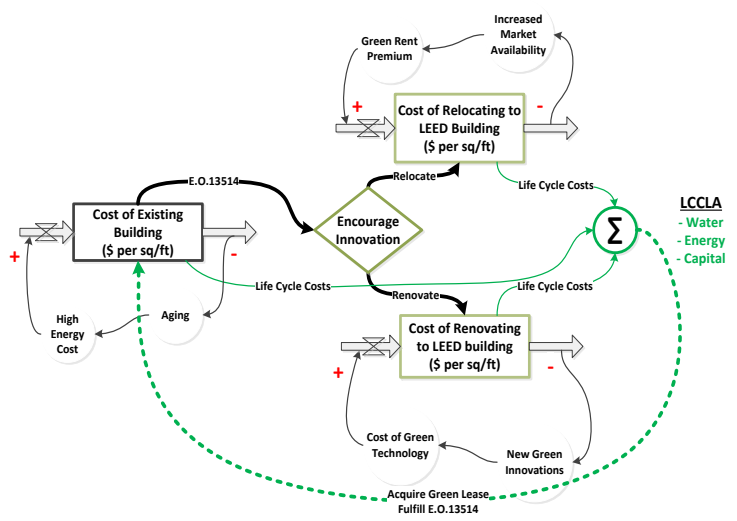

Fig. 3. Building Lease Process Factors

\section{STAKEHOLDERS}

There are four major stakeholders in this project: the FAA, Real Estate Contracting Officers (RECO), Lessor, and the FAA Employees.

TABLE I

STAKEHOLDER OBJECTIVES AND TENSIONS

\begin{tabular}{|c|c|c|}
\hline Stakeholders & Objectives & Tensions \\
\hline $\begin{array}{c}\text { Federal Aviation } \\
\text { Administration (FAA) }\end{array}$ & $\begin{array}{c}\text { Develop/lmplement } \\
\text { sustainability policy and } \\
\text { plans }\end{array}$ & $\begin{array}{c}\text { Additional } \\
\text { requirement/Existing } \\
\text { resources }\end{array}$ \\
\hline $\begin{array}{c}\text { Real Estate Contracting } \\
\text { Office (RECO) }\end{array}$ & NegotiationNPayment & $\begin{array}{c}\text { Obtain space within } \\
\text { existing budget }\end{array}$ \\
\hline Lessor & Provide space & $\begin{array}{c}\text { LEED certification/and } \\
\text { still make profit }\end{array}$ \\
\hline FAA Employees & $\begin{array}{c}\text { Perform safety and } \\
\text { regulatory } \\
\text { responsibilities }\end{array}$ & $\begin{array}{c}\text { Want good working } \\
\text { conditions }\end{array}$ \\
\hline
\end{tabular}

\section{A. Federal Aviation Administration (FAA)}

Objective: Develop the sustainability policy and plan, approve initiatives and interim targets, and report progress.

Tension: Their primary mission is Aviation and Safety. The E.O.13514 is an additional mandate that needs to be financed with existing resources.

\section{B. Real Estate Contracting Officers (RECOs)}

Objective: Negotiate and sign leases for the FAA. 
Tension: The Lessor wants RECOs to pay for this additional requirement since they are the ones that will be renting the space.

\section{Lessor}

Objective: Lessor is the owner of the property.

Tension: Lessors do not want to pay for renovations costs, and want FAA to pay for any upfront certification cost.

\section{FAA Employees/Union}

Objective: Employees are required to finish all tasks on time therefore employees demand good working conditions.

Tension: If the FAA chooses to relocate, employees' working conditions may change. Labor unions may wish to negotiate those changes, resulting in possible down time or other additional cost. In the end, they want to see the results because they demand good working conditions and do not want to really see a change in their space.

\section{E. RECO Leasing Process}

The Real Estate Contract Officers follow a process for the acquisition of real property assets.

The process is initiated by a tenant organization which has a lease that is due to expire. There are two types of leases that can be pursued. The first is what is known as a full service lease. This type of lease will include payment of all utilities in the rent costs. The other is a partial service lease which includes operation and maintenance costs but not utilities.

After the space requirements have been agreed upon, the process of finding a suitable building, which meets those space requirements, begins. The RECO will perform a market survey to assess what prices are fair and reasonable, and then will place an advertisement in the media that is most likely to yield the most results. Potential lessors will then contact the RECO and make their best offer.

The RECO will then evaluate each offer based on the lowest cost per square foot, and select two to four that best meet the requirements of the tenant organization.

Negotiations begin with those lessors. The current focus for the RECOs when entering these negotiations is only on up front rent costs and not on life cycle costs of the lease. The contract negotiations can last from a few weeks to a year or more. Since the interim target set by E.O. 13514 is $15 \%$ green buildings by FY 2015, this does not lend itself well to lengthy negotiations.

In order for the RECO to conduct a full life cycle cost analysis on all building they must spend additional time and resources. The RECO's currently only focus on upfront cost per square foot costs and do not take into account the life cycle cost and individual buildings benefits. The effort of this team is to help the RECO in performing this analysis and identify buildings that will satisfy the E.O.13514 at minimal or positive costs.

\section{Problem Statement}

E.O.13514 sets an interim objective stating that $15 \%$ of each agency's buildings (>5000 sq. $\mathrm{ft}$. and occupied) must be HPSB's by 2015, with annual progress toward $100 \%$ thereafter. To reach the objectives stated in E.O. 13514, the FAA has begun the identification process for conversion of its owned properties, direct leased GSA leased, federally owned and FAA controlled buildings. This project will focus on directly leased buildings from private lessors. As of 2012, the FAA has $<1 \%$ of their direct lease buildings identified for conversion. There is no additional funding provided for acquiring new HPSB buildings. Analysis is necessary to determine what actions the FAA should take in identifying which direct lease buildings would be the most beneficial to convert to HPSB. Currently, RECO analyses are focused upon obvious, upfront rent cost and not on lifecycle costs vs. benefits. Based on feedback from FAA Logistics Management, if the current path is maintained, the FAA will not meet the Executive Order's objective of $15 \%$ its buildings compliant by 2015 .

\section{NEEDS STATEMENT}

The FAA needs a process that analyzes lifecycle costs of buildings with consideration of individual benefits that green buildings will provide. This process will be applied to the direct lease buildings inventory in order to identify 15 buildings for conversion to HPSB. These buildings will help the FAA reach their overall goal of $15 \%$ as identified in the E.O.13514. There are many stakeholders involved with this problem and each has their own objectives which creates some tensions. To satisfy the tension that exists between the oversight group of stakeholders and those tasked with implementation of new policies, this system should be able to allow a "win-win" solution for the FAA to meet the target set by E.O. 13514 and the financial goal of net-zero lifecycle cost. The system should also be able to allow for the minimization of impact to the employees that may be affected by any resultant action.

\section{MISSION REQUIREMENTS}

1. The system shall analyze the costs and benefits for each alternative for each building taking into account the entire length of the lease, energy savings, and utility gained.

2 . The system shall rand most cost effective buildings and their respected alternative.

3. The system shall predict time to breakeven with $95 \%$ confidence.

4. The system shall calculate total life-cycle savings with 95\% confidence.

\section{Design Alternatives}

Three alternatives were considered for each building that the system analyzed: Status Quo, Renovation, and relocation.

\section{A. Status Quo}

Status quo, no changes are made and the lease is renewed as usual. The benefits of this option are that the cost remains the same and there is no impact to employees. However, this 
option has no effect on the efficiency of the building and it does not contribute to the accomplishment of the goals set by E.O. 13514.

\section{B. Renovation}

Renovating the building, the RECO negotiates that the lessor will add provisions to the current building that will allow for LEED Silver certification. Lessors will most likely try to offset the costs of those conversions by raising the rent a significant amount. This option contributes to the accomplishment of E.O. 13514's goal, but has higher upfront costs. Since there are savings in energy throughout the lifecycle of the building, those costs maybe offset over the length of the lease. There is an added benefit of job satisfaction for employees in working in a renovated, green building.

\section{Relocation}

Relocation is moving to a building that already holds a LEED Silver certification. This option has the potential to be the most energy efficient and thus, the least amount of energy cost. However, this option entails a relocation cost that can be quite expensive and therefore contributes significantly to initial costs. Additionally, there are many impacts to employees that must be considered. Some of those impacts include, accessibility to public transportation, and change in commute. A major benefit for those employees is increased productivity and job satisfaction from working in a new building.

\section{SySTEM MODEL}

Inputs for lease data come from the FAA's Real Estate Management System (REMS). Lease term, number of employees, location, building size, and capital costs come from this database. Energy unit prices and projection data come from the Energy Information Administration (EIA) and utility consumption data from the Commercial Building Energy Consumption (CBEC) survey. The data from the EIA and the CBEC was used to calculate general energy consumption figures to use in the calculations since actual data for the buildings was unavailable. General Services Administration (GSA) case studies were reviewed in order to generate rent increases and renovation costs that are associated with green buildings. Water consumption was projected by the Federal Water Index that was provided by the Department of Energy. Initial relocation costs were calculated by contacting independent moving companies.

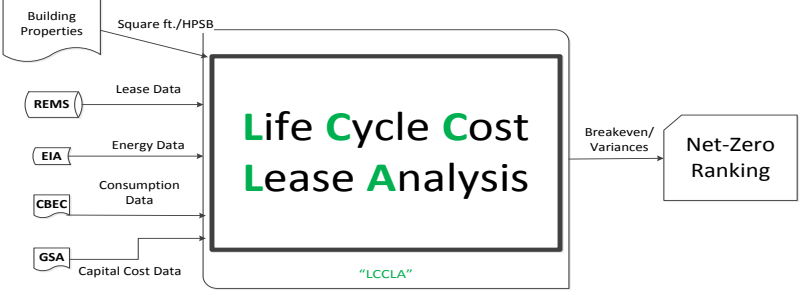

Fig. 4. Input/Output System Model.
Oracle's Crystal Ball simulation software used to perform Monte Carlo simulation of the outcomes for variation of the input parameters and final outputs gave the mean life cycle costs and variances for each design alternative, the time to break even, and the rank of each building from most to least cost effective.

\section{Method of AnAlysis}

The financial benefits of building leasing are determined based on a three phase process illustrated in Figure 5.

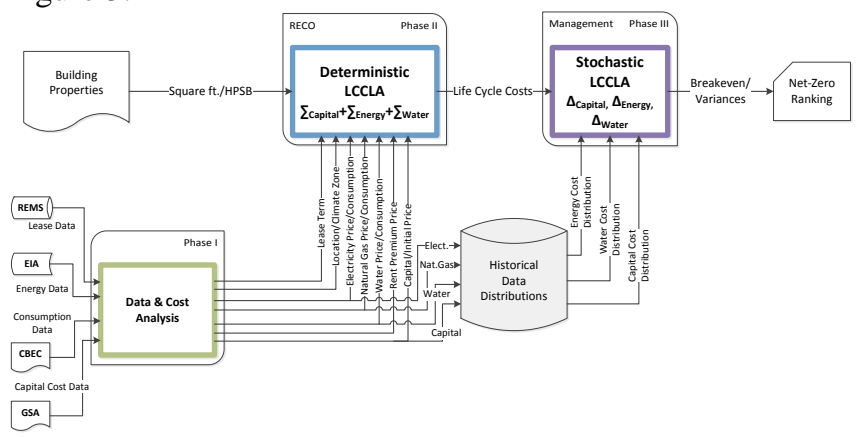

Fig. 5. Full System Model

\section{A. Data Analysis (Phase One)}

This stage gathered all relevant data that will be used in the project. The FAA's REMS database was used to gather current building information. The EIA information was used to calculate energy prices and projections for electricity and Natural Gas. The CBEC survey was used to identify building class and building energy consumption because no consumptions data is currently recorded by the FAA.

\section{B. OMB Analysis (Phase Two)}

OMB Cir A-94 titled "Guidelines and Discount Rates for Benefit-Cost Analysis of Federal Programs".

The purpose of this government wide standard is: "to promote efficient resource allocation through well-informed decision-making by the Federal Government. It provides general guidance for conducting benefit-cost and costeffectiveness analyses. It also provides specific guidance on the discount rates to be used in evaluating Federal programs whose benefits and costs are distributed over time. The general guidance will serve as a checklist of whether an agency has considered and properly dealt with all the elements for sound benefit-cost and cost-effectiveness analyses". [1]

This OMB standard has two parts the system equation shown in equation (1) and the federally accepted calculation, Building Life Cycle Cost (BLCC). Phase two of the simulation was developed to adhere to this standard. The BLCC, however, cannot calculate different alternatives or deal with stochastic variables. Furthermore, it requires the user to enter each alternative and build energy unit price, rent, consumption, and initial investment.

The total system equation is a summation of four components: Electricity, Natural Gas, Water, and Rent. 


$$
L C C L A={ }_{t=0}^{N} \frac{C_{\text {Elec }}}{(1+d)^{t}}+{ }_{t=0}^{N} \frac{C_{N G}}{(1+d)^{t}}+{ }_{t=0}^{N} \frac{C_{\text {Water }}}{(1+d)^{t}}+{ }_{t=0}^{N} \frac{C_{\text {Re } n t}}{(1+d)^{t}}(1)
$$

Variables

1) $N=$ Length of Lease

2) $d=$ Discount Rate: used to adjust cash flow to present value, derive values from Price Index Tables found in $O M B$ Cir. A-94

3) $C_{\text {Elec }}=$ Annual Electricity Cost

4) $C_{N G}=$ Annual Natural Gas Cost

5) $C_{\text {Water }}=$ Annual Water/Disposal Cost

6) $C_{\text {Rent }}=$ Annual Rent Cost

C. Life Cycle Cost Lease Analysis vs. Current FAA Analysis

Based on the research and the calculation made with the Phase 2 simulation, each building's Life Cycle Cost was calculated for each design alternative. Every building was assumed to have partial service leases in order to show savings that will incur due to energy costs and consumptions. This calculation included: capital investment, energy, water, inflation, and other costs with respect to climate and region. Based on stakeholder information, this method was compared to the current method followed by the FAA, which is to simply look at cost per square foot.

\section{Stochastic Simulation (Phase Three)}

Oracle's Crystal Ball was used to perform a Monte Carlo simulation. This was needed because price projections are never perfect and need to be varied to show a more realistic life cycle cost estimate. Each selected building was calculated 50,000 times. The probability of break-even was calculated, along with a $95 \%$ confidence interval of each lease.

\section{E. Value Hierarchy}

In addition to monetary considerations, the utility of different attributes must be added to the function to give value to non-monetary considerations. Some of those attributes that are being weighed at this time are illustrated in Figure 6.

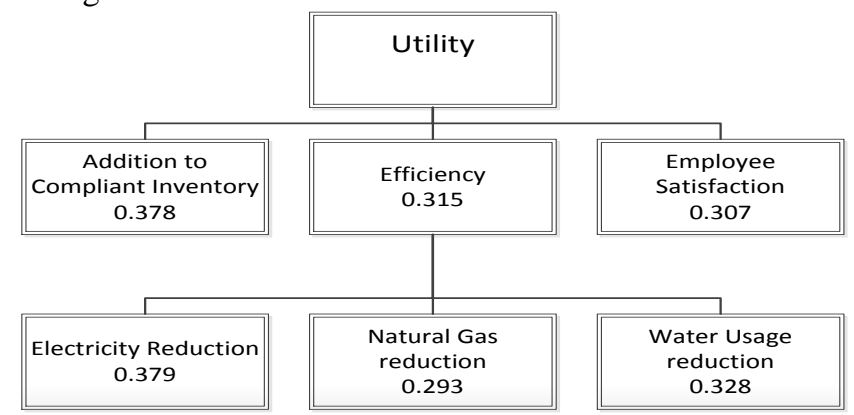

Fig. 6. Utility Hierarchy

A survey of ten questions was sent to 20 stakeholders that gauged the importance of each attribute. A scale of one to ten was used to establish the weights that would be used. The responses to those questions were averaged and then normalized using the swing weight method to establish the weights that would be used in the utility function. The results from the survey revealed that E.O. compliance, efficiency, and employee satisfaction were weighted evenly. The parameters within efficiency were also closely ranked with natural gas savings coming in last at $29 \%$. Building rankings by utility showed that larger buildings yielded higher utility. Ranking buildings using this utility analysis showed that larger buildings would be the best candidates due to bigger reduction in energy consumption. However, due to the FAA's limited resources, the team was asked to ranked buildings by E.O. compliance and cost effectiveness.

\begin{tabular}{|c|c|c|c|c|c|c|}
\hline Rank & STATE & lease Contract & Square Feet & Net-Zero & 95\% CI Variance & Utility \\
\hline 1 & DC & $X X X X: X X X X X X 62656$ & 40,363 & $\$ 416,091$ & $\$ 1,420,704$ & 34193 \\
\hline 2 & $C A$ & $X X X X X-X X-X X X-001 C B$ & 123,876 & $\$ 200,219$ & $\$ 1,112,147$ & 111421 \\
\hline 3 & PA & $X X X X-X X: X X-00009$ & 14,602 & $\$ 85,782$ & $\$ 854,098$ & 11591 \\
\hline 4 & N & $x x x x-x X x-x X-00017$ & 14,000 & $\$ \$ 9,90$ & $\$ 851,372$ & 11076 \\
\hline 5 & MT & $X X X X X X X X-X X-00015$ & 23,47 & $\$ 48,627$ & $\$ 850,441$ & 18493 \\
\hline 6 & ME & $X X X X X-X X X-X X X-R 1844$ & 10,800 & $\$ 33472$ & $\$ 988,855$ & 8564 \\
\hline 7 & ME & $x x x x-x x-x x=00010$ & 7,500 & $\$ 14,460$ & $\$ 851,589$ & 6705 \\
\hline 8 & VA & $x x x x-x x-x x-62481$ & 15,155 & $\$ 7,2 \pi$ & 5848,597 & 11978 \\
\hline 9 & PA & $X X X X-X X-X X-16427$ & 6,700 & $\$ 355$ & $\$ 627,984$ & 5998 \\
\hline 10 & NM & $X X X X X-X X X-X X-01361$ & 5,618 & $\$ 340$ & $\$ 8,750$ & 5045 \\
\hline 11 & MO & $X X X X X-X X X-X X-00116$ & 7,645 & $\$ 3,281$ & $\$ 834,920$ & 6834 \\
\hline 12 & Ml & $X X X X-X X X-X X-00138$ & 10,000 & $-\$ 4,271$ & $\$ 837,726$ & 8909 \\
\hline 13 & OR & $x x x x-x x-x X x-00193$ & 5,200 & $-\$ 5,081$ & $\$ 645,531$ & 4677 \\
\hline 14 & $C A$ & $x x x x-x X-x X-00012$ & 5,000 & $-56,328$ & $\$ 837,425$ & 4501 \\
\hline 15 & AK & $X X X X X-X X X-X X X-00009$ & 8,700 & $-56,895$ & $\$ 639,745$ & 7759.76 \\
\hline
\end{tabular}

Table 2 shows the top fifteen buildings showing either a positive savings, net zero financial impact or lowest costs to acquire a renovated green building.

TABLE II

TOP LEASES FOR CONVERSION

\begin{tabular}{|c|c|c|c|c|c|c|}
\hline Rank & STATE & lease Contract & Squarefeet & Net-Zero & o5s Cl Variance & Utility \\
\hline 1 & $D C$ & 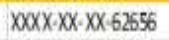 & 40,367 & $\$ 416,091$ & $\$ 1,400,704$ & 34193 \\
\hline 2 & $C A$ & $X X X X X-X X X-X X X-D O 1 C B$ & $123,8 \%$ & $\$ 200,219$ & $\$ 1,112,147$ & 111421 \\
\hline 3 & $P A$ & $X X X X-X X-X X X-00009$ & 14,662 & $\$ 85,782$ & $\$ 854,098$ & 11591 \\
\hline 4 & N & $x x X X X-X X X-X X X-00017$ & 14,000 & $\$ \$ 9,90$ & $\$ 851,372$ & 11076 \\
\hline 5 & MT & $X X X X-X X X-X X-00015$ & 23,47 & $\$ 48,627$ & $\$ 850,441$ & 18493 \\
\hline 6 & ME & $x x x x-x x-x x-R 1844$ & 10,800 & $\$ 33,472$ & $\$ 988,855$ & 8564 \\
\hline 7 & ME & $x x x x-x x-x x=00010$ & 7,500 & $\$ 14,460$ & $\$ 851,589$ & 6705 \\
\hline 8 & VA & $x x x x-x x-x x-62481$ & 15,155 & $\$ 7,2 \pi$ & $\$ 248,597$ & 11978 \\
\hline 9 & PA & $X X X X X-X X-X X-16427$ & 6,700 & $\$ 355$ & $\$ 627,984$ & 5998 \\
\hline 10 & NM & $x x x x-x x-x x-01361$ & 5,618 & $\$ 340$ & $\$ 8,750$ & 5045 \\
\hline 11 & MO & $x x x x-x x-x x-00116$ & 7,645 & $-\$ 3281$ & $\$ 834,920$ & 6834 \\
\hline 12 & Mil & $x x x x-x x-X X X-00138$ & 10,000 & $-\$ 4,27 \pi$ & $\$ 837,726$ & 8909 \\
\hline 13 & $O R$ & $x x x x-x x-x x-00193$ & 5,200 & $-55,081$ & S245,531 & 4677 \\
\hline 14 & $C A$ & $x x X X X-X X-X X X-00012$ & 5,000 & $-56,328$ & 5837,425 & 4501 \\
\hline 15 & AK & $x x x x-x x-x-x x-00009$ & 8,700 & $-56,898$ & $\$ 839,745$ & 7759.76 \\
\hline
\end{tabular}

\section{RECOMMENDATIONS}

\section{A. Target Smaller Buildings}

All but one of the buildings in Table 2 is less than 12,500 square feet. This is a result of the lower cost of renovation of smaller buildings. 
As shown in Fig. 7, a Life Cycle Cost Lease Analysis (LCCLA) is preferable to the current analysis approach that the FAA uses. Their present analysis accounts only for rent costs per square feet and not any savings from energy efficiency that the lessor may incur.

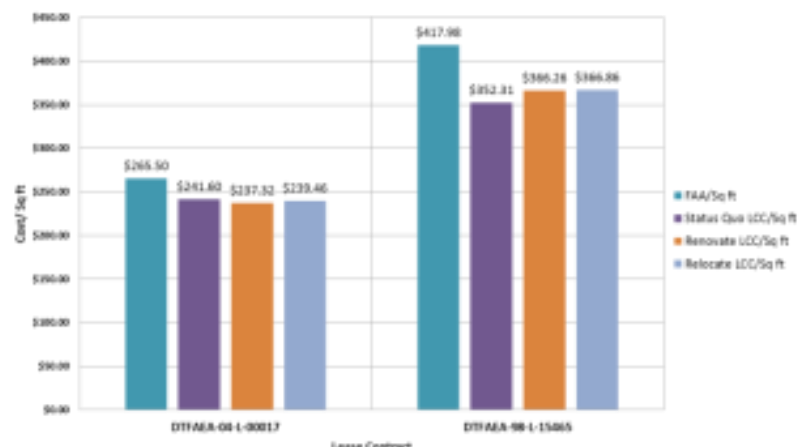

Fig. 7. Current FAA analysis vs LCC analysis for 2 Leases.

The buildings represented here are approximately the same sizes and lease terms. The lease on the right with a lease contract number ending with 15465 has nearly twice as many occupants. This demonstrates that the location of a building has the greatest impact on the savings, not the number of occupants.

\section{B. Capital Expenses Driving Force}

Rent is the largest contributor to costs. As rent does not change throughout the term of the lease, it has little potential to contribute to savings. In a green building, the savings are not in rent. The savings are only in energy and water efficiency. The greatest savings potential lies in areas where energy costs are highest. Therefore, the most cost effective buildings to target are ones in areas with low capital rent costs and high energy prices.

\section{Partial Service Leases}

The analysis also reveals that full service leases do not allow the FAA to reap the benefits of the green technology. Since the responsibility of paying utilities falls to the lessor, the lessor is in a position to charge a premium rent to cover the stochastic energy costs. If those costs are actually less than what was negotiated, the lessor can pocket the difference. Partial service leases give finer control over money for utility bills.

\section{Behavior Adjustments Through Feedback}

This method of leasing also has the capability of giving immediate feedback as to the performance of the efficiency of the building. If a full service lease cannot be avoided, the RECO should negotiate for a lower rent because the lessor will be receiving the benefits of the building's efficiency.

\section{ACKNOWLEDGMENT}

Thanks to our sponsors Ajay Sharma and Abijit Adhikari (FAA), Susan Frost and Kelly Vielmo (Price Waterhouse Cooper), and Dr. Lance Sherry, Paula Lewis, Juan Mantilla, and Dr. George Donohue(George Mason University) for their invaluable guidance throughout this project.

\section{REFERENCES}

[1] N/A "Executive Order 13423 Strengthening Federal Environmental, Energy, and Transportation Management" gpo.gov [Online]. Available: http://www.gpo.gov/fdsys/pkg/FR-2007-01-26/pdf/07374.pdf. [Accessed:10/29/2012]

[2] N/A “Annual FAA Budget for Office Organization" faa.gov [Online]. Available:

http://www.faa.gov/about/budget/http://www.faa.gov/about/office_org /headquarters_offices/aba/admin_factbook. [Accessed:11/01/2012]

[3] N/A "Budget" faa.gov [Online]. Available: http://www.faa.gov/about/budget/. [Accessed:11/19/12]

[4] N/A "Current Inflation Rates" inflationdata.com [Online]. Available: http://inflationdata.com/Inflation/Inflation_Rate/CurrentInflation.asp. [Accessed:11/29/2012]

[5] N/A "Executive Order 13423 Strengthening Federal Environmental, Energy, and Transportation Management" gpo.gov [Online]. Available: http://www.gpo.gov/fdsys/pkg/FR-2007-01-26/pdf/07374.pdf. [Accessed:10/29/2012]

[6] N/A "Executive Order 13514 Federal Leadership in Environmental, Energy, and Economic Performance" gpo.gov [Online]. Available: http://www.gpo.gov/fdsys/pkg/FR-2009-10-08/pdf/E9-24518.pdf. [Accessed:11/25/2012]

[7] N/A "Green Building Asset Valuation: Trends and Data" institutebe.com [Online]. Available: http://www.institutebe.com/InstituteBE/media/Library/Resources/Gre en\%20Buildings/Research_Snapshot_Green_Building_Asset_Value.p df. [Accessed:11/20/2012]

[8] N/A "Guiding Principles for Federal Leadership in High Performance and Sustainable Buildings" energystar.gov [Online]. Available: http://www.energystar.gov/ia/business/Guiding_Principles.pdf. [Accessed:10/20/2012]

[9] N/A "Federal Aviation Administration-FY 2012 Strategic Sustainability Plan" gpo.gov [Online]. Available: http://www.gpo.gov/fdsys/pkg/FR-2007-01-26/pdf/07-374.pdf. [Accessed:11/29/2012]

[10] N/A "FAA Lifecycle Management Process Flowchart" fast.faa.gov [Online]. Available: http://www.gpo.gov/fdsys/pkg/FR-2007-0126/pdf/07-374.pdf. [Accessed:11/05/2012]

[11] N/A "Federal Leadership in High Performance and Sustainable Buildings Memorandum of Understanding" energystar.gov [Online]. Available:http://www.energystar.gov/ia/business/Guiding_Principles. pdf. [Accessed:10/20/2012]

[12] N/A "Leadership in Energy and Environmental Design" new.usgbc.org [Online]. Available: https://new.usgbc.org/leed. [Accessed:11/19/2012]

[13] N/A "Manager of Resource Management for Region and Center Operations and FAA" gpo.gov [Online]. Available: http://www.faa.gov/about/office_org/headquarters_offices/aba/admin factbook. [Accessed:10/25/2012]

[14] N/A "Real-estate Management System REMS Excel File from OCT 1 2012" [Not Available] [Accessed:11/29/2012]

[15] N/A "Regions and Aeronautical Center Operations" faa.gov [Online] Available:

http://www.faa.gov/about/office_org/headquarters_offices/arc/. [Accessed: 10:13:12]

[16] The Office of Management and Budget Circular No. A-94 Revised The White House http://www.whitehouse.gov/omb/circulars_a094\#1

[17] http://www.whitehouse.gov/administration/eop/ceq/sustainability

[18] http://www.whitehouse.gov/the-press-office/president-obama-setsgreenhouse-gas-emissions-reduction-target-federal-operations

[19] http://www1.eere.energy.gov/femp/program/sustainable_iswgresource s.html

[20] http://www.whitehouse.gov/administration/eop/ceq/about

[21] http://www.whitehouse.gov/administration/eop/ceq/sustainability/omb -scorecards

[22] http://fasteditapp.faa.gov/ams/do_action 